\title{
PKC $\alpha$ expression is a marker for breast cancer aggressiveness
}

\author{
Gry Kalstad Lønne, Louise Cornmark, Iris Omanovic Zahirovic, Göran Landberg, Karin Jirström, Christer Larsson ${ }^{*}$
}

\begin{abstract}
Background: Protein kinase C (PKC) isoforms are potential targets for breast cancer therapy. This study was designed to evaluate which PKC isoforms might be optimal targets for different breast cancer subtypes.

Results: In two cohorts of primary breast cancers, PKC $\alpha$ levels correlated to estrogen and progesterone receptor negativity, tumor grade, and proliferative activity, whereas PKC $\delta$ and PKC $\varepsilon$ did not correlate to clinicopathological parameters. Patients with PKC $\alpha$-positive tumors showed poorer survival than patients with PKC $\alpha$-negative tumors independently of other factors. Cell line studies demonstrated that PKC $\alpha$ levels are high in MDA-MB-231 and absent in T47D cells which proliferated slower than other cell lines. Furthermore, PKC $\alpha$ silencing reduced proliferation of MDA-MB-231 cells. PKC $\alpha$ inhibition or downregulation also reduced cell migration in vitro.
\end{abstract}

Conclusions: PKC $\alpha$ is a marker for poor prognosis of breast cancer and correlates to and is important for cell functions associated with breast cancer progression.

\section{Background}

Breast cancer is a heterogeneous disease which encompasses several subgroups with different morphology, genetic changes, and response to therapies [1,2]. It is therefore important to gain more insight into relevant therapeutic targets for each subgroup to optimize tailored treatment protocols for individual patients. Numerous intracellular signaling proteins have been suggested to be promising targets for blocking the malignancy of breast cancer cells. The protein kinase $\mathrm{C}$ (PKC) isoforms are examples of such potential therapeutic targets.

PKC is a family of serine/threonine kinases involved in several processes including proliferation, differentiation, apoptosis, and migration. The PKC isoforms are divided into three subgroups depending on the structure of the regulatory domain: classical (PKC $\alpha, \beta \mathrm{I}, \beta \mathrm{II}$, and $\gamma$ ), novel $(\mathrm{PKC} \delta, \varepsilon$, and $\theta$ ), and atypical (PKC $\zeta$ and $\mathrm{t} / \lambda$ ) isoforms. Classical and novel PKCs contain a diacylglycerol (DAG)-binding $\mathrm{C} 1$ domain and are therefore regulated by activation of pathways that lead to DAG generation. Atypical PKCs are DAG-insensitive and regulated in a different manner [3].

\footnotetext{
* Correspondence: Christer.Larsson@med.lu.se

Center for Molecular Pathology, Department of Laboratory Medicine, Lund University, Malmö University Hospital, SE- 20502 Malmö, Sweden
}

Several studies have implicated the DAG-sensitive classical and novel PKC isoforms in promoting malignant features of breast cancer cells. PKC $\alpha$ has been coupled to estrogen receptor (ER) negativity [4] and estrogen-independent growth of cultured cells [5,6] and patients with PKC $\alpha$-negative tumors had better response to endocrine treatment compared to patients with PKC $\alpha$-positive tumors [7,8]. Moreover, increased PKC $\alpha$ expression leads to a more aggressive phenotype [4] and is associated with resistance to cytostatic drugs in MCF-7 cells $[9,10]$. PKC $\alpha$ is also evaluated as a therapeutic target for breast cancer [11]. However, PKC $\alpha$ levels are reduced in breast cancer compared to normal breast tissue $[12,13]$. Thus, there is evidence for both a promoting and a suppressing role for PKC $\alpha$ in breast cancer.

The role of $\mathrm{PKC} \delta$ in breast cancer is ambiguous. Patients with $\mathrm{PKC} \delta$-positive tumors show better endocrine response compared to patients with $\mathrm{PKC} \delta$-negative tumors [8] and PKC $\delta$ has been shown to be crucial for UV light-induced apoptosis of cultured breast cancer cells [14]. However, several studies point to a protumorigenic role of $\mathrm{PKC} \delta$ in breast cancer. $\mathrm{PKC} \delta$ can induce resistance to tamoxifen and irradiation in cultured breast cancer cells $[15,16]$ and has been shown to promote both metastasis [17-19] and proliferation [20] 
of murine mammary cancer and epithelial cells. We have recently shown that depletion of PKC $\delta$ is sufficient to drive breast cancer cells into apoptosis [21].

PKC $\varepsilon$ has frequently been assigned oncogenic effects in breast cancer. Expression levels of PKC $\varepsilon$ have been shown to correlate with tumor grade, HER2 expression, ER negativity, and poor survival in breast cancer patients. Moreover, in MDA-MB-231 breast cancer cells, downregulation of $\mathrm{PKC} \varepsilon$ reduced the tumor growth and metastatic capacity in mice [22]. There is also evidence that $\mathrm{PKC} \varepsilon$ protects cells against apoptotic insults [23-25].

Taken together, the available in vitro and in vivo data highlight $\mathrm{PKC} \alpha, \mathrm{PKC} \delta$, and $\mathrm{PKC} \varepsilon$ as future candidates for targets in breast cancer therapy and as markers for disease prognosis. However, so far there is limited knowledge on the potential of the different isoforms as diagnostic and prognostic markers in breast cancer. This study sheds light on this issue by analyzing the expression levels of these PKC isoforms in primary breast cancer tissue and our results indicate that $\mathrm{PKC} \alpha$ is a potential marker of breast cancer aggressiveness.

\section{Methods}

\section{Cell culture}

All cell lines were obtained from ATCC. MCF-7, MDAMB-231, and MDA-MB-468 breast cancer cells were maintained in RPMI 1640 medium (Sigma) supplemented with $10 \%$ fetal bovine serum (FBS; Invitrogen), $1 \mathrm{mM}$ sodium pyruvate (PAA laboratories $\mathrm{Gmbh}$ ), $100 \mathrm{IU} / \mathrm{ml}$ penicillin, and $100 \mu \mathrm{g} / \mathrm{ml}$ streptomycin (both Gibco). T47D cells were grown in DMEM supplemented with 10\% FBS, $10 \mathrm{mM}$ HEPES (PAA laboratories Gmbh), $100 \mathrm{IU} / \mathrm{ml}$ penicillin, and $100 \mu \mathrm{g} / \mathrm{ml}$ streptomycin. The media for MCF-7 and T47D cells were additionally supplemented $0.01 \mathrm{mg} / \mathrm{ml}$ insulin (Novo Nordisk A/S).

\section{Transfections}

For siRNA transfections, cells were seeded at $35-50 \%$ confluency and grown in complete medium without antibiotics for 24 hours. Cells were transfected for 48 hours using $4 \mu \mathrm{l} / \mathrm{ml}$ Lipofectamine 2000 (Invitrogen) and $40 \mathrm{nM}$ siRNA (Invitrogen, table 1) in Optimem (Gibco) according to supplier's protocol.

\section{Table 1 siRNA oligonucleotides}

\begin{tabular}{ll}
\hline siRNA & Oligonucleotides \\
\hline Control & GACAGUUGAACGUCGAUUUGCAUUG \\
PKC $\alpha \# 1$ & CCGAGUGAACUCACGGACUUCAAU \\
PKC $\alpha \# 2$ & CCAUCGGAUUGUUCUUUCUUCAUAA \\
PKC $\delta$ & CCAAGGUGUUGAUGUCUGUUCAGUA \\
PKC $\varepsilon$ & CACAAGUUCGGUAUCCACAACUACA \\
\hline
\end{tabular}

Plasmid transfections were carried out for five hours replacing normal medium with Optimem containing $2 \mu \mathrm{l} / \mathrm{mL}$ Lipofectamine 2000 and $2 \mu \mathrm{g} / \mathrm{mL}$ DNA according to supplier's protocol. Plasmids encoding PKC constructs fused to enhanced green fluorescent protein (EGFP) have been described previously [26].

\section{Tumor material}

Cohort I originally consisted of tumors from 114 patients diagnosed with breast cancer at Umeå University Hospital and treated according to regional guidelines. The cohort is described in table 2. Due to lack of tumor material in the tissue microarray, 42-60 tumors could be analyzed, depending on the parameter investigated. Ki-67 had been classified in two groups $<20 \%$ and $>20 \%$ positive cells.

Cohort II included 512 consecutive breast cancer cases diagnosed at the department of Pathology, Malmö University Hospital, between 1988 and 1992. The cohort is described in table 2. Due to lack of tumor material in the tissue microarray, 223-263 tumors could be analyzed, depending on the parameter investigated. Ki-67 had been classified in three groups, $0-10 \%, 11-25 \%$ and 26-100\% positive cells.

The cohorts represented a mix of all histological subtypes in proportions corresponding to the common incidence. The construction of tissue microarrays and clinicopathological properties of the cohorts have been described in detail elsewhere [27-32]. Ethical permissions were obtained from the Lund and Umeå Ethical Boards. The number of tumors that could not be evaluated for PKC expression due to lack of material is indicated as not evaluated in the tables.

\section{Cell pellet arrays}

Cells were washed in phosphate-buffered saline (PBS) and fixed for 25 minutes in $4 \%$ paraformaldehyde in PBS with Mayer's hematoxylin $(5 \mu \mathrm{l} / \mathrm{ml})$ present during the last 5 minutes. The cells were pelleted, paraformaldehyde was removed and they were thereafter incubated

\section{Table 2 Characteristics of the cohorts investigated}

\begin{tabular}{lcc}
\hline Cohort & I & II \\
\hline Number of patients & 114 & 512 \\
Age at diagnosis, median (range) & $60(30-80)$ & $65(27-96)$ \\
Tumor size (mm), median (range) & $22(8-100)$ & $16(1-100)$ \\
\hline Nodal status & & \\
Positive & 53 & 168 \\
Negative & 48 & 298 \\
Missing & 13 & 58 \\
\hline ER-status & & 417 \\
Positive & 82 & 72 \\
Negative & 31 & 35 \\
Missing & 1 & \\
\hline
\end{tabular}


over night in $70 \%$ ethanol followed by dehydration using increasing concentrations of ethanol and finally xylen. After dehydration, cell pellets were embedded in paraffin and arranged in a cell line array.

\section{Immunohistochemistry}

Sections $(4 \mu \mathrm{m})$ of the paraffin blocks were dried, deparaffinized, rehydrated and microwave-treated in $1 \times$ target retrieval solution with high $\mathrm{pH}$ (DAKO). All sections were stained in a DAKO Techmate ${ }^{\mathrm{TM}}$ machine and visualized using DAB. The antibodies used were PKC $\alpha$ (1:2000), PKC $\delta$ (1:1000), PKC $\varepsilon$ (1:400; all Santa Cruz Biotechnology, product numbers sc-208, sc-937 and sc-214), and Ki-67 (1:200; DAKO). All tissue microarray slides of a cohort were stained simultaneously with the same staining solutions ensuring identical conditions for each tumor. PKC stainings were scored according to cytoplasmic staining intensity were 0 representing lack of staining, 1 low staining, 2 moderate staining, and 3 strong staining. All cohorts were examined independently by two investigators and disconcordant results were re-evaluated. For Ki-67 analyses of breast cancer cell lines, Ki-67 staining intensity was scored as negative-low or moderate-strong staining.

\section{Sample preparation and Western blot}

Cells were washed twice in ice-cold PBS and lyzed with RIPA buffer (10 mM Tris- $\mathrm{HCl} \mathrm{pH} 7.2,160 \mathrm{mM} \mathrm{NaCl}$, $1 \%$ Triton-X 100, $1 \%$ sodium deoxycholate, $0.1 \%$ sodium dodecyl sulfate, $1 \mathrm{mM}$ EDTA, $1 \mathrm{mM}$ EGTA) supplemented with $40 \mu \mathrm{l} / \mathrm{ml}$ complete protease inhibitor (Roche Applied Science) for 30 minutes on ice. Lysates were cleared by centrifugation at $14,000 \times g$ for $10 \mathrm{~min}$ utes at $4^{\circ} \mathrm{C}$.

Proteins were separated with SDS-PAGE and transferred to polyvinylidene difluoride membranes (Millipore). Membranes were blocked with PBS containing $0.05 \%$ tween and $5 \%$ non-fat milk, and probed with antibodies towards PKC $\delta$ (1:500), PKC $\varepsilon$ (1:500), PKC $\alpha$ (1:3000), and actin (1:2000; MP Biomedicals, clone C4). Proteins were visualized with horseradish peroxidaselabeled secondary antibody (Amersham Biosciences) using the SuperSignal system (Pierce Chemical) as substrate. The chemiluminescence was detected with a CCD camera (Fuji Film).

\section{Analysis of cell growth (WST-1 assay)}

Cell were seeded at a density of 2000 cells per well in 96-well culture plates, and incubated for 24 hours. For cell line comparison, viable cell number was measured 24 and 48 hours after seeding. For experiments with inhibition or activation of PKC, $2 \mu \mathrm{M}$ Gö6976 (Calbiochem) or equal volume DMSO, or 16 nM 12-O-tetradecanoylphorbol-13acetate (TPA; Sigma) was added in complete medium
(CM) or serum-free medium (SFM) 24 hours after seeding, and cells were incubated for 72 hours prior to estimation of viable cell number. The amount of viable cells was assessed by a WST-1 cell viability assay (Roche Applied Science). Absorbance was measured in an ELISA plate reader Antos 2020 (Antos Labtech Instruments).

\section{Immunofluorescence and confocal microscopy}

Immunofluorescence of $\mathrm{PKC} \alpha$ was done as described [33] using Alexa Fluor 488-conjugated secondary antibodies. Cells were examined with a Zeiss LSM 710 confocal system using standard settings for Alexa Fluor 488.

\section{Cell cycle analysis}

MDA-MB-231 cells were seeded at a density of 100,000 cells per $35 \mathrm{~mm}$ cell culture dish and transfected with siRNA. After transfection, cells were incubated in SFM or CM for 24 hours. Cells were trypsinized and fixed in $70 \%$ ethanol for 20 minutes at $-20^{\circ} \mathrm{C}$, washed in PBS, and incubated with a solution containing $3.5 \mu \mathrm{M}$ Tris$\mathrm{HCl} \mathrm{pH} 7.6,10 \mathrm{mM} \mathrm{NaCl}, 50 \mu \mathrm{g} / \mathrm{ml}$ propidium iodide (PI), $20 \mu \mathrm{g} / \mathrm{ml}$ RNase, and $0.1 \%$ igepal CA-630 for 20 minutes on ice in order to label DNA. 10,000 events were acquired on the FL-2 channel for the PI signal. Sample acquisition and analyses were performed with CellQuest software (Becton Dickinson).

\section{Wound healing assay}

MDA-MB-231 or MCF-7 cells were seeded at a density of 150,000 cells per $35 \mathrm{~mm}$ cell culture dish and transfected with siRNA. After transfection, a scratch was made with a $200 \mu$ l pipette tip in a confluent area of the cell culture dish. Photographs of a selected area of each scratch were taken at indicated time points. For experiments with PKC inhibitors, MDA-MB-231 cells were seeded at a density of 350,000 cells per $35 \mathrm{~mm}$ cell culture dish and incubated for 24 hours before a scratch was made and PKC inhibitors were added. Photographs of a selected area of each scratch were taken 0 and 16 hours after scratching. The remaining wound area was measured using ImageJ software.

\section{Statistics}

For TMA analysis, correlations between variables were calculated using Pearson's two-tailed significance test. Differences in distribution of various clinicopathological parameters in regard to PKC expression were also calculated using the $\chi^{2}$-test. The Kaplan-Meier analysis and the log rank test were used to illustrate differences between recurrence-free survival (RFS) and breast cancer-specific survival (BCSS) according to PKC expression. Cox regression proportional hazards models were used to estimate the impact of PKC $\alpha$ expression on breast cancer-specific survival in both univariate and 
multivariate analysis, adjusted for Nottingham histological grade (NHG), age, lymph node status, and tumor size of cohort II. For in vitro experiments, the significance of difference was assessed by analysis of variance (ANOVA) followed by Duncan's multiple range test. The difference was considered significant if the $p$-value was $<0.05$. All statistical calculations were performed using SPSS V.11.0.

\section{Results}

\section{PKC expression in breast cancer tumors}

Two cohorts of primary breast cancers (see experimental procedures for details) were analyzed for expression of PKC isoforms. Several batches of antibodies were tested to identify antibodies that did not cross-react with other isoforms. Cross reaction is a notorious problem for analyses of PKC isoforms. For PKC $\alpha$, PKC $\delta$, and $\mathrm{PKC} \varepsilon$ we had access to antibodies that did not cross-react with other isoforms (Figure 1A and 1B). As can be seen in Figure 1A there is only strong immunoreactivity in some of the cells where the cognate isoform has been overexpressed. In Figure 1B it can be seen that downregulation with siRNA abolishes or markedly diminishes the staining with the antibody towards the cognate isoform.

When present in a tumor, all of the PKC isoforms investigated were generally cytoplasmic and expressed in all of the tumor cells. Therefore, only the cytoplasmic staining intensity was accounted for in the analyses. Figure 1C-J show examples of tumors with different staining intensities of $\mathrm{PKC} \alpha$, from negative to strong staining.

Initially a TMA of a smaller cohort (cohort I) was evaluated (Table 3 and 4). There was a significant correlation between $\mathrm{PKC} \alpha$ staining intensity and lack of ER $(\mathrm{p}<0.001)$ and progesterone receptor $(\mathrm{PR} ; \mathrm{p}=0.002)$ as well as with tumor grade $(\mathrm{p}=0.001)$ and proliferation rate (Ki-67; p < 0.001). PKCa levels did not correlate significantly with other clinicopathological parameters such as local or distal metastases (Table 3). For PKC $\delta$ and $\mathrm{PKC} \varepsilon$ there were no significant correlations with any of the clinicopathological parameters analyzed (Table 3).

A larger cohort (cohort II; Table 3 and 4) was then analyzed for expression levels of $\mathrm{PKC} \alpha$, since this isoform correlated to several clinicopatohological parameters in the first cohort, and $\mathrm{PKC} \varepsilon$, since our data somewhat contradict a published study [22]. The results from cohort II corroborated the findings in cohort I, where tumors with high PKC $\alpha$ levels had a higher proliferation rate $(\mathrm{p}<0.001)$, were ER $(\mathrm{p}<0.001)$ and PRnegative $(\mathrm{p}<0.001)$, and of a higher histological grade $(\mathrm{p}<0.001)$. Furthermore, a $\chi^{2}$ analysis demonstrated that there is not an equal distribution of tumors with high and low PKC $\alpha$-levels in the different histological subgroups in cohort II (Table 4). The skewed distribution is related to the tumors of medullary subtype. A tumor was defined as medullary if it fulfilled the following criteria: 1) lymphocytoplasmic reaction, 2) microscopic circumscription, 3) a syncytial growth pattern, and 4) poorly differentiated nuclear grade and high mitotic rate. For this group two out of twelve investigated tumors (17\%) had high PKC $\alpha$ expression levels whereas the corresponding number for all evaluated breast cancers was five of $250(2 \%)$. Only $8 \%$ of the medullary tumors were PKC $\alpha$-negative, compared to $72 \%$ for all tumors. Thus, there is an overrepresentation of medullary carcinomas among tumors with high $\mathrm{PKC} \alpha$ levels. For $\mathrm{PKC} \varepsilon$, the findings were similar to cohort I, with no correlation to any relevant clinicopathological parameters.

\section{PKC $\alpha$ expression is associated with poor prognosis}

We next analyzed the relationship between the expression of PKC $\alpha$ and PKCE and 10-year survival of the patients (Figure 2). As illustrated in figure 2A, lower $\mathrm{PKC} \alpha$ levels were associated with a significantly prolonged 10-year RFS ( $\mathrm{p}=0.050)$. A similar trend was also seen for 10-year BCSS, but this did not reach statistical significance (Figure $2 \mathrm{C} ; \mathrm{p}=0.116$ ). Since the majority of the tumors are negative for PKC $\alpha$ and the other groups (staining intensity 1-3) are small, a dichotomized variable defined as absent staining versus any staining was used for the same analyses of recurrencefree and breast cancer-specific survival. When dichotomized, PKC $\alpha$ positivity was associated with a non-significant trend towards a poorer 10-year RFS, figure 2B; $\mathrm{p}=0.074)$. However, patients with $\mathrm{PKC} \alpha$-negative tumors had a significantly improved 10-year BCSS compared to patients with $\mathrm{PKC} \alpha$-positive tumors (Figure 2D; $\mathrm{p}=0.016$ ). We also performed a Cox regression proportional hazards analysis, demonstrating estimates of relative risks (RR) according to $P K C \alpha$ expression in univariate and multivariate analyses, adjusted for age at diagnosis, tumor size, NHG, node status and ER expression (Table 5). This revealed that the association between PKC $\alpha$ positivity and a poor 10-year BCSS was independent of established prognostic parameters (multivariate $\mathrm{RR}=2.123,95 \% \mathrm{CI} 1.092$ to 4.126, $\mathrm{p}=0.026$ ).

Since a majority of the medullary carcinomas analyzed were PKC $\alpha$-positive and patients with these tumors generally have good prognosis [34] we also examined 10-year BCSS after excluding patients with medullary carcinomas and found that PKC $\alpha$ remained an independent prognostic factor (Table 5).

Recurrence-free or breast cancer-specific 10-year survival was not significantly influenced by $\mathrm{PKC} \varepsilon$ expression, neither for all groups (staining intensity $0-3$ ) nor 
A

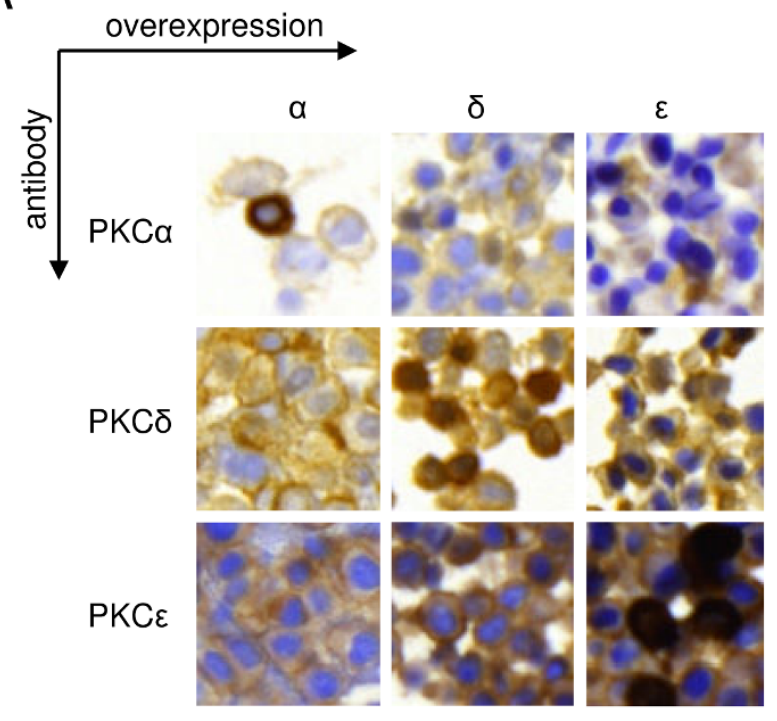

B

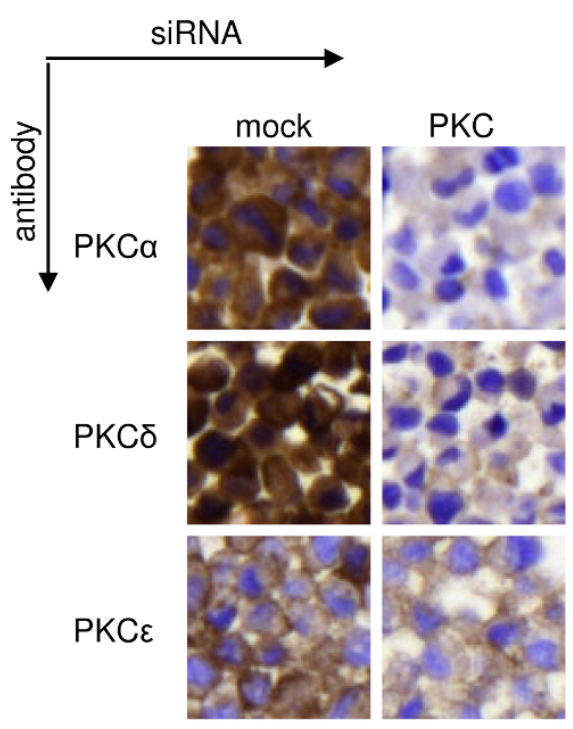

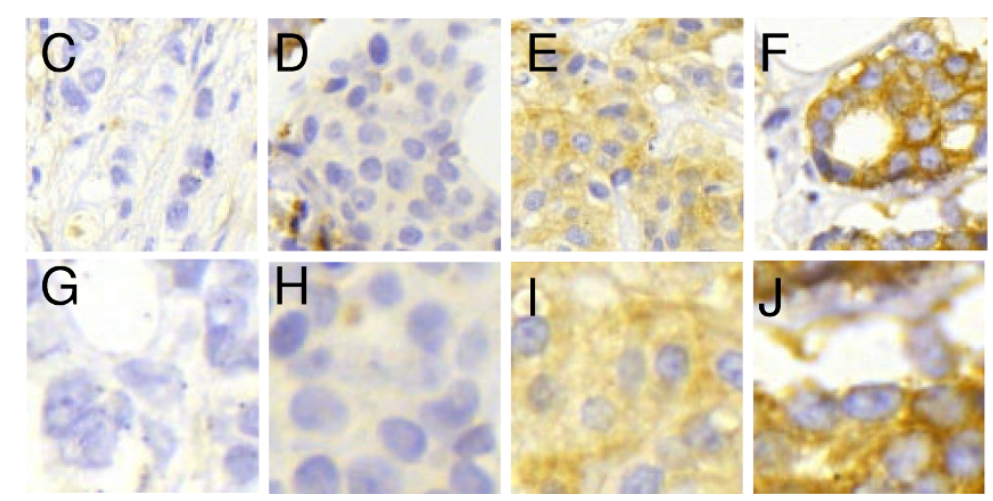

Figure 1 Immunohistochemical stainings of primary breast cancer and validation of antibody specificity. MCF-7 cells were transfected with vectors encoding PKC $\alpha(\alpha)$, PKC $\delta(\delta)$, or PKC $\varepsilon(\varepsilon)(A)$ and MDA-MB-231 cells were mock-treated or transfected with siRNA targeting PKC $\alpha$ $(\alpha)$, PKC $\delta(\delta)$, or PKC $\varepsilon(\varepsilon)(B)$. Pellets of transfected cells were arranged in a cell line array and immunohistochemistry was performed with antibodies towards indicated PKC isoforms. (C-J) Examples of immunohistochemical staining of PKC $\alpha$ in breast cancer specimens from cohort II showing negative ( $C$ and $G$ ), low $(D$ and $H)$, moderate ( $E$ and $I)$, and intense ( $F$ and J) staining with 20x magnification (C-F) and with 40x magnification (G-J).

when dichotomized into staining intensity $0-2$ versus 3 (Figure 2E-H). A higher cutoff was chosen for dichotomization of $\mathrm{PKC} \varepsilon$ due to a smaller proportion of negative tumors.

\section{PKC expression in breast cancer cell lines}

To evaluate whether different breast cancer cell lines may represent the PKC isoform expression pattern in tumors, we measured PKC levels in four breast cancer cell lines (Figure 3A). High PKCa levels were seen in MDA-MB-231 cells compared to MCF-7 and
MDA-MB-468 cells. PKC $\alpha$ was undetectable in T47D cells. PKC $\delta$ levels were higher in MCF-7 cells, whereas for PKC\& no major differences in expression levels could be noted.

To investigate whether the relationship between PKC $\alpha$ and a high proliferation rate observed in the tumors can be seen in cell lines as well, we examined the proliferation rate of the cell lines (Figure 3B and 3C). T47D, which had no detectable PKC $\alpha$, was the least proliferative cell line, supporting the tumor data. On the other hand, for MDA-MB-231 which clearly had the highest 
Table 3 Associations between PKC $\alpha$, PKC $\delta$, and PKC $\varepsilon$ intensity and clinicopathological variables in cohort $I$ and II.

\begin{tabular}{|c|c|c|c|c|c|}
\hline \multirow{2}{*}{$\frac{\text { Cohort }}{\text { Variable }}$} & \multicolumn{2}{|l|}{1} & \multicolumn{3}{|c|}{ II } \\
\hline & $\operatorname{PKC} \alpha$ & PKC $\delta$ & PKC $\varepsilon$ & $\mathrm{PKC} \alpha$ & $\mathrm{PKC} \varepsilon$ \\
\hline \multicolumn{6}{|l|}{$\overline{\mathrm{NHG}}$} \\
\hline$\rho$ & 0.401 & -0.049 & -0.029 & 0.247 & -0.011 \\
\hline$p$ & 0.001 & 0.719 & 0.833 & $<0.001$ & 0.863 \\
\hline n & 60 & 57 & 55 & 249 & 263 \\
\hline \multicolumn{6}{|c|}{ Estrogen receptor } \\
\hline$\rho$ & -0.482 & 0.210 & -0.016 & -0.334 & 0.068 \\
\hline$p$ & $<0.001$ & 0.120 & 0.907 & $<0.001$ & 0.273 \\
\hline $\mathrm{n}$ & 59 & 56 & 54 & 244 & 261 \\
\hline \multicolumn{6}{|c|}{ Progesterone receptor } \\
\hline$\rho$ & -0.402 & -0.081 & -0.216 & -0.280 & 0.062 \\
\hline$p$ & 0.002 & 0.554 & 0.120 & $<0.001$ & 0.342 \\
\hline$n$ & 58 & 55 & 53 & 223 & 240 \\
\hline \multicolumn{6}{|c|}{ Ki-67 positivity } \\
\hline$\rho$ & 0.535 & 0.229 & 0.280 & 0.295 & -0.056 \\
\hline$p$ & $<0.001$ & 0.144 & 0.069 & $<0.001$ & 0.363 \\
\hline$\underline{n}$ & 46 & 42 & 43 & 244 & 261 \\
\hline \multicolumn{6}{|c|}{ Nodal status } \\
\hline$\rho$ & -0.027 & 0.095 & -0.002 & 0.029 & 0.028 \\
\hline$p$ & 0.842 & 0.495 & 0.987 & 0.666 & 0.667 \\
\hline $\mathrm{n}$ & 56 & 54 & 52 & 224 & 233 \\
\hline \multicolumn{6}{|c|}{ Distant metastasis } \\
\hline$\rho$ & 0.159 & 0.162 & -0.064 & 0.090 & 0.037 \\
\hline$p$ & 0.226 & 0.227 & 0.642 & 0.159 & 0.556 \\
\hline$n$ & 60 & 57 & 55 & 247 & 261 \\
\hline
\end{tabular}

$\rho$ : Pearson's correlation coefficient. $p<0.05$ in bold. $n$ : number of tumor samples.

PKC $\alpha$ levels, 97\% of the cells had moderate or strong Ki-67 staining intensity (Figure 3B). For the cell lines with lower but detectable PKC $\alpha$ levels, MCF-7 and MDA-MB-468, the corresponding numbers were $88 \%$ and $91 \%$, respectively. This did not differ significantly from MDA-MB-231 cells which would not be expected considering that the fraction of positive cells was close to $100 \%$ in these cell lines. The Ki-67 data were supported by the growth rate of the cell lines as estimated by a ratio of viable cell number after $48 \mathrm{~h}$ in culture with the number obtained after $24 \mathrm{~h}$ (Figure 3C).

\section{PKC $\alpha$ is crucial for breast cancer cell proliferation under serum-free conditions}

To further examine whether PKC $\alpha$ is important for proliferation of breast cancer cells, the effects of a PKC activator and an inhibitor were studied (Figure 4A-C). Under serum-free conditions, activation of PKC by TPA was not sufficient to increase cell growth, as indicated by the amount of viable cells which represents the summative effect of proliferation and cell death. TPA did influence PKC $\alpha$ as seen by a relocation of PKC $\alpha$ to the plasma membrane and enrichment in the nucleus of both MCF-7 and MDA-MB-231 cells (Figure 4D). This indicates that $\mathrm{PKC} \alpha$ is activated but the total levels of PKC $\alpha$ were also reduced following TPA treatment (Figure $4 \mathrm{E}$ ) which complicates the estimation of the net effect of TPA on PKC $\alpha$ in the cells.

Gö6976, an inhibitor of classical PKCs, did not significantly reduce the number of cells indicating that PKC $\alpha$ activity is not critical for the growth of breast cancer cells under normal conditions.

PKC $\alpha$ has been shown to promote proliferation independently of its catalytic activity [35]. This fact together with the fact that both TPA and Gö6976 can have unspecific effects beside modulation of PKC $\alpha$ activity led us to more specifically analyze the role of PKC $\alpha$ by using siRNA oligonucleotides followed by analysis of cell cycle distribution. PKC $\alpha$ levels were downregulated in MDAMB-231 cells with both siRNAs targeting PKC $\alpha$ and this did not influence the expression levels of the other PKC isoforms investigated (Figure 5A). Only one of the PKCa oligonucleotides $(\alpha \# 1)$ significantly influenced the cell cycle distribution when cells were grown in serum-containing complete medium (CM; Figure 5B). The oligonucleotide slightly decreased the amount of cells in S-phase compare to control. However, under serum-free medium (SFM) downregulation of PKC $\alpha$ with either siRNA led to significantly decreased amount of cells in S-phase compared to control cells (Figure 5C). The result indicates that PKC $\alpha$ plays an important role for proliferation of cells particularly under sub-optimal conditions. Under optimal growth conditions PKC $\alpha$ may be redundant for proliferation.

\section{PKC $\alpha$ activity is necessary for migration of breast cancer cells}

In breast cancer, PKC $\alpha$ has been associated with an increased ability of cells to migrate, since overexpression of PKC $\alpha$ has been shown to promote migration and metastasis of breast cancer cells [4,36,37]. Based on this we aimed at examining the importance of endogenous PKC $\alpha$ for breast cancer cell motility. Wound healing assays were performed with MDA-MB-231 cells in the absence or presence of PKC inhibitors (Figure 6A). Inhibition of classical PKCs (Gö6976) or classical and novel PKCs (GF109203X) suppressed the wound closure to $34 \%$ and $56 \%$, respectively, of the DMSO treated cells, indicating that $\mathrm{PKC}$ activity is important for the ability of MDA-MB-231 cells to migrate. Since PKC inhibitors are isoform-unspecific, we downregulated $\mathrm{PKC} \alpha$ with siRNA in MDA-MB-231 cells prior to a wound-healing assay, to more specifically study the role of PKC $\alpha$ in migration. However, downregulation of PKC $\alpha$ did not affect the migration of MDA-MB-231 cells (Figure 6B). 
Table 4 Associations between PKC $\alpha$, PKC $\delta$, and PKC $\varepsilon$ intensity and histological type in cohort I and II.

\begin{tabular}{|c|c|c|c|c|c|c|c|}
\hline Cohort I & & Ductal & Lobular & Medullary & Mucinous & & \\
\hline PKC $\alpha$ intensity & 0 & 25 & 3 & 0 & 2 & & \\
\hline \multirow[t]{4}{*}{$p^{*}=0.295$} & 1 & 20 & 0 & 1 & 0 & & \\
\hline & 2 & 4 & 0 & 0 & 0 & & \\
\hline & 3 & 4 & 0 & 1 & 0 & & \\
\hline & n.e. & 42 & 3 & 0 & 2 & & \\
\hline PKC $\delta$ intensity & 0 & 12 & 0 & 0 & 1 & & \\
\hline \multirow[t]{4}{*}{$p^{*}=0.850$} & 1 & 33 & 1 & 2 & 1 & & \\
\hline & 2 & 7 & 0 & 0 & 0 & & \\
\hline & 3 & 0 & 0 & 0 & 0 & & \\
\hline & n.e. & 43 & 5 & 0 & 2 & & \\
\hline PKC $\varepsilon$ intensity & 0 & 0 & 0 & 0 & 0 & & \\
\hline \multirow[t]{4}{*}{$p^{*}=0.800$} & 1 & 12 & 0 & 1 & 0 & & \\
\hline & 2 & 29 & 1 & 1 & 2 & & \\
\hline & 3 & 9 & 0 & 0 & 0 & & \\
\hline & n.e. & 45 & 5 & 0 & 2 & & \\
\hline Cohort II & & Ductal & Lobular & Medullary & Mucinous & Tubular & Mixed \\
\hline $\mathrm{PKC} \alpha$ intensity & 0 & 124 & 17 & 1 & 10 & 14 & 13 \\
\hline \multirow[t]{4}{*}{$p^{*}<0.001$} & 1 & 34 & 4 & 5 & 2 & 3 & 3 \\
\hline & 2 & 10 & 0 & 4 & 0 & 0 & 1 \\
\hline & 3 & 3 & 0 & 2 & 0 & 0 & 0 \\
\hline & n.e. & 168 & 52 & 3 & 5 & 17 & 17 \\
\hline PKC $\varepsilon$ intensity & 0 & 2 & 1 & 0 & 0 & 0 & 0 \\
\hline \multirow[t]{4}{*}{$p^{*}=0.328$} & 1 & 38 & 9 & 7 & 4 & 5 & 5 \\
\hline & 2 & 90 & 19 & 4 & 7 & 9 & 7 \\
\hline & 3 & 41 & 5 & 1 & 1 & 1 & 7 \\
\hline & n.e. & 168 & 39 & 3 & 5 & 19 & 15 \\
\hline
\end{tabular}

${ }^{*} \chi^{2}$-test, $\mathrm{p}<0.05$ in bold, n.e. $=$ not evaluated

MDA-MB-231 cells have high basal levels of PKC $\alpha$ compared to the other cell lines investigated in this study (Figure 3A). Transfection of these cells with siRNA targeting PKC $\alpha$ might not sufficiently reduce the PKC $\alpha$ levels. A comparison with MCF-7 cells (Figure 6C) actually demonstrates that following siRNA treatment of MDA-MB-231 cells the PKC $\alpha$ levels in these cells are roughly the same as in MCF-7 cells. Therefore, to obtain a more substantial PKC $\alpha$ depletion we downregulated $\mathrm{PKC} \alpha$ in MCF-7 cells and thereafter performed a wound healing assay (Figure 6E). PKC $\alpha$ silencing in MCF-7 cells did not influence the other PKC isoforms investigated (Figure 6D). In these cells downregulation of $\mathrm{PKC} \alpha$ significantly reduced migration into the wound to $55 \%$ of the control cells (Figure 6E). The results suggest that PKC $\alpha$ activity is crucial for migration of breast cancer cells in vitro.

\section{Discussion}

Several studies have suggested that DAG-sensitive PKC isoforms contribute to the progression of breast cancer and the malignant characteristics of breast cancer cells. In particular the $\mathrm{PKC} \alpha, \mathrm{PKC} \delta$, and $\mathrm{PKC} \varepsilon$ isoforms have been highlighted as potential targets for therapy of breast cancer or of specific subsets of the disease. This led us to design this study in which the expression of these PKC isoforms in primary breast cancer tumors has been examined to assess their utility as markers of tumor aggressiveness.

To substantiate the analysis, two different cohorts of primary breast cancer tumors were used, and the results from the cohorts were similar. We found significant correlations between PKC $\alpha$ levels and several markers of tumor aggressiveness including ER negativity. A correlation between PKC $\alpha$ levels and ER negativity has also been observed in a recent study [8] using 70 tumors from patients that had received systemic endocrine therapy. They also showed that high PKC $\alpha$ levels predicted a worse outcome in response to endocrine therapy, which is also supported in an earlier study with a smaller number of patients [7]. Our data, as demonstrated in two separate cohorts, firmly establish the relationship between PKC $\alpha$ and ER negativity. In addition, we identify a clear correlation between PKC $\alpha$ and PR negativity, and a positive correlation with tumor grade and high proliferation rate, further supporting the notion that 

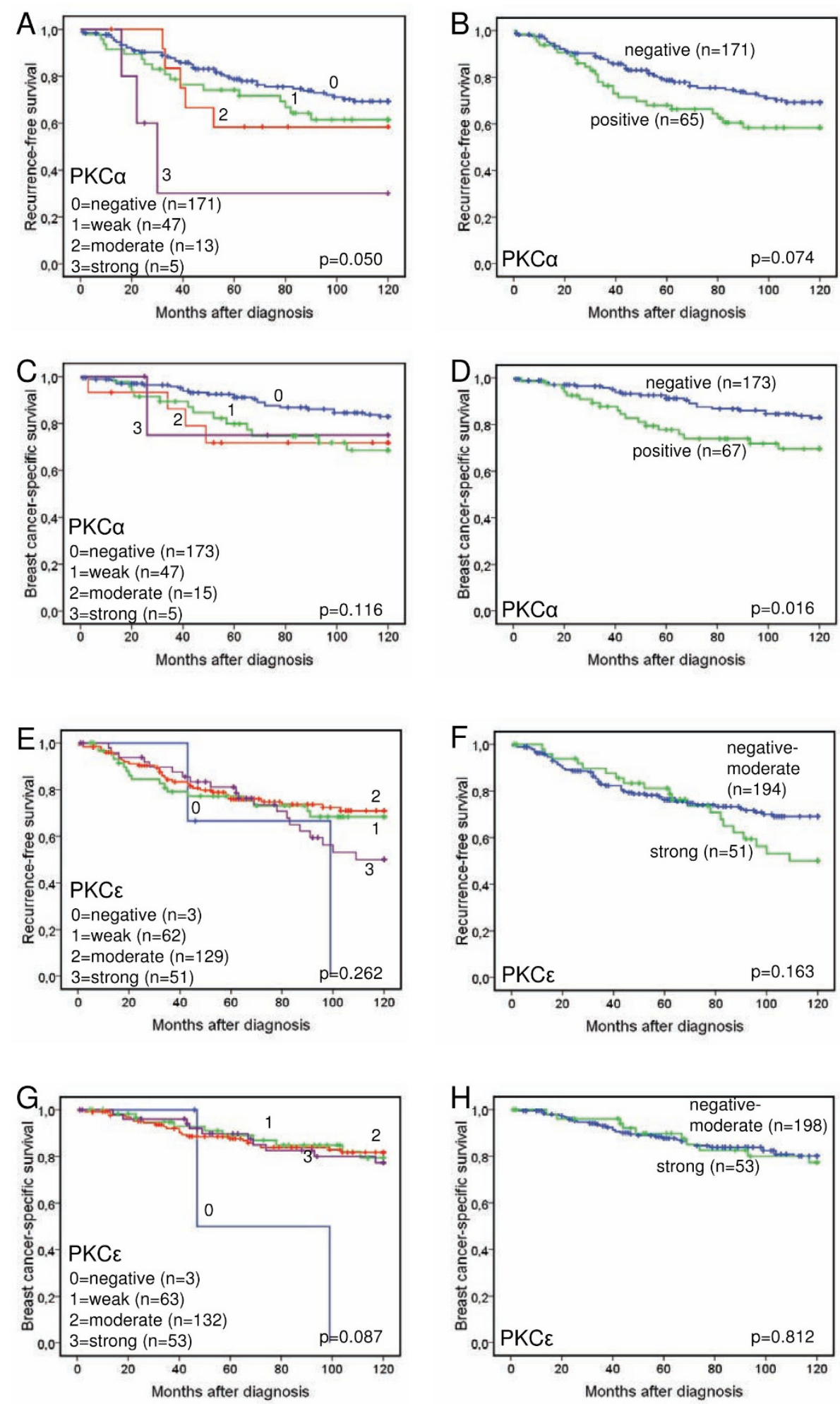

Figure 2 Recurrence-free survival and breast cancer-specific survival according to PKC $\alpha$ and PKC $\varepsilon$ expression. Kaplan-Meier estimates of 10 year recurrence-free survival (A-B and E-F) and breast cancer-specific survival (C-D and G-H) according to PKC $\alpha$ (A-D) and PKC $\varepsilon$ (E-H) expression. 
Table 5 Cox univariate and multivariate analysis of breast cancer-specific survival in cohort II according to PKC $\alpha$ expression in all patients and when patients with medullary cancer are excluded.

\begin{tabular}{lllll}
\hline & \multicolumn{2}{c}{ All patients } & \multicolumn{2}{c}{$\begin{array}{c}\text { Medullary cancers } \\
\text { excluded }\end{array}$} \\
\cline { 2 - 5 } & RR (95\%Cl) & $\begin{array}{l}\boldsymbol{p} \\
\text { value }\end{array}$ & RR (95\%Cl) & $\begin{array}{l}\boldsymbol{p} \\
\text { value }\end{array}$ \\
\cline { 2 - 5 } & Univariate & & Univariate \\
PKC $\alpha$ & 1.00 & & 1.00 & \\
negative & & & & \\
PKC $\alpha$ & $2.105(1.148$ to & 0.016 & $1.995(1.069$ to & 0.030 \\
positive & $3.862)$ & & $3.721)$ & \\
& & & & \\
& Multivariate & & Multivariate & \\
PKC $\alpha$ & 1.00 & & 1.00 & \\
negative & & 0.026 & $1.978(0.984$ to & 0.055 \\
PKC $\alpha$ & 2.123 (1.092 to & & $3.975)$ & \\
positive & $4.126)$ & &
\end{tabular}

Multivariate analysis adjusted for Nottingham histological grade (I-II/III), age (continuous), nodal status (0/1), tumor size (continuous), and ER $(<$ or $>10 \%)$.

PKC $\alpha$ expression is associated with parameters related to tumor aggressiveness. Finally, PKC $\alpha$ expression predicts a worse disease outcome with a significantly poorer 10-year breast cancer-specific survival for patients with primary tumors that were PKC $\alpha$-positive. The results from the multivariate analysis further indicate that $\mathrm{PKC} \alpha$ is an independent prognostic factor in breast cancer.

However, other studies have indicated that PKC $\alpha$ levels actually are decreased in breast cancer compared to normal breast tissue $[12,13]$. This may not necessarily contradict our findings since a vast majority of the cancer samples in our material were essentially PKC $\alpha$-negative, which is in line with the notion that PKC $\alpha$ downregulation is a common event during breast cancer progression. Therefore, the published data, together with our results, suggest that most breast cancers are PKC $\alpha$-negative, but that there are smaller subgroups with higher PKC $\alpha$ levels, displaying more aggressive clinicopathological features. If $\mathrm{PKC} \alpha$ is to be used as a target for breast cancer therapy these data highlight the need to evaluate PKC $\alpha$ levels prior to such intervention.

In the largest cohort (II) there was also a significant association of PKC $\alpha$ levels with histological subtypes. Cancers with medullary histology were over-represented in the group with high PKC $\alpha$ levels. In addition, the only medullary cancer in cohort I was PKC $\alpha$-positive.

In line with the tumor data demonstrating that PKC $\alpha$ levels correlate with features of aggressiveness, an association of PKC $\alpha$ with malignant features has also been seen in breast cancer cell lines. Increased levels of PKC $\alpha$ correlate to and can induce tamoxifen [38,39] and multidrug $[9,10]$ resistance of ER-positive cell lines. In addition,

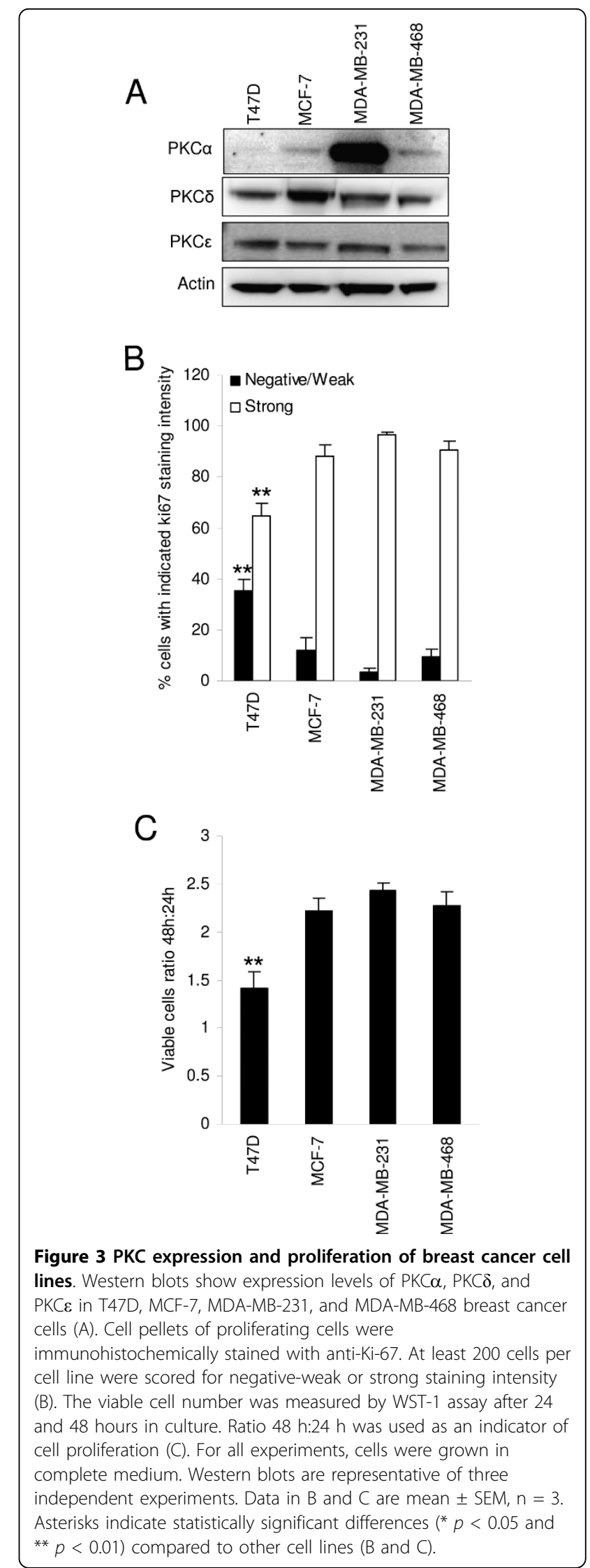




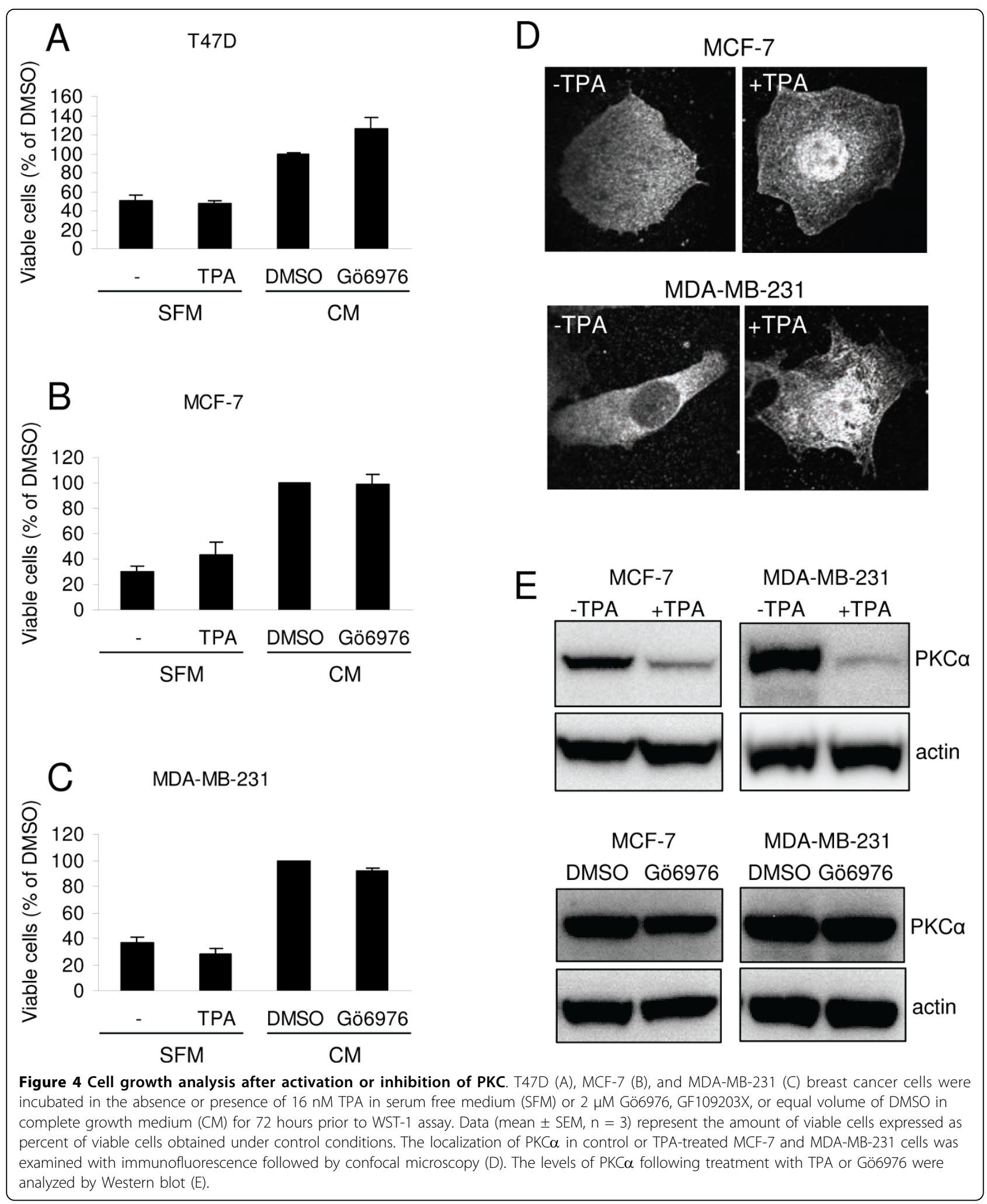




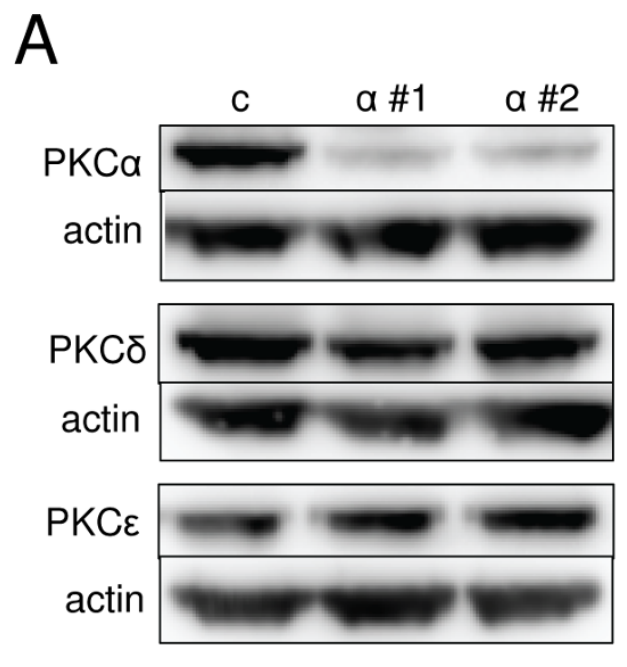

B

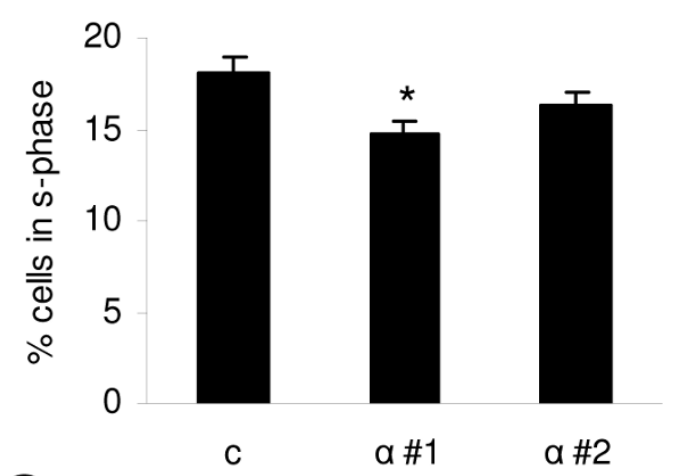

C

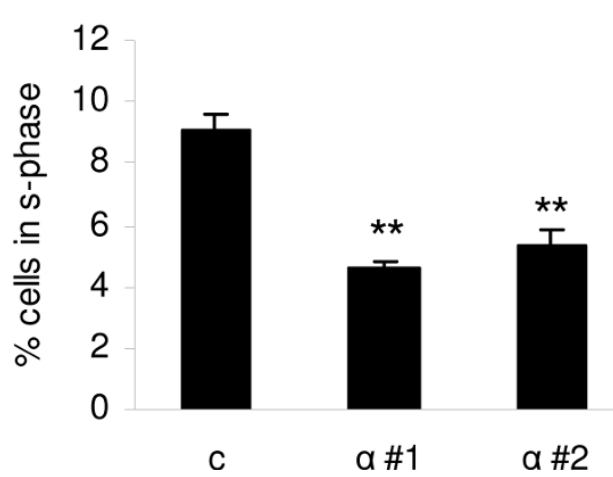

Figure 5 Cell cycle distribution of MDA-MB-231 cells with downregulated PKC $\alpha$. MDA-MB-231 cells were transfected with two different siRNAs targeting PKC $\alpha(\alpha \# 1$ and $\alpha \# 2)$ or a control oligonucleotide. After transfection, cells were incubated with complete medium (CM) or serum-free medium (SFM) for 24 hours. Adherent cells were thereafter subjected to Western blot (A) or propidium iodide staining and flow cytometry (B and $C$ ). Western blots are representative of three independent experiments. Data in $\mathrm{B}$ and $\mathrm{C}$ (mean $\pm \mathrm{SEM}, \mathrm{n}=3$ ) show the percentage of cells in $\mathrm{s}$ phase. overexpression of PKC $\alpha$ in MCF-7 cells leads to increased proliferation which is in line with our tumor data [4], but also make them more susceptible to apoptotic insults $[40,41]$. We found that the cell line with no detectable PKC $\alpha$ expression, T47D, had a lower percentage of Ki-67positive cells and slower growth rate than the other cell lines, similar to the tumor data. However, the cell line with the highest PKC $\alpha$ expression, MDA-MB-231, only had marginally higher Ki-67 positivity compared with cell lines with detectable but much lower expression. This may be related to the fact that the fraction of Ki-67-positive cells was high (97\%) and could not be further elevated.

Neither inhibition of PKC $\alpha$ in the presence of serum nor PKC activation under serum-starvation influenced the growth of the cell lines in a manner that would support an essential role for PKC $\alpha$ for breast cancer cell growth. A recent paper has shown that the PKC $\alpha$ protein, but not activity, is essential for glioma cell proliferation [35]. We found that downregulation of PKC $\alpha$ with siRNA caused a modest effect on cell cycle distribution of MDA-MB-231 cells grown in complete medium. However, under serum-free conditions, PKC $\alpha$ silencing clearly reduced the amount of proliferating cells suggesting that, as in glioma cells, the PKC $\alpha$ protein, but maybe not its catalytic activity, supports proliferation under sub-optimal conditions.

Studies in vitro have demonstrated that increasing the PKC $\alpha$ expression in MCF-7 cells makes them more migratory in response to PKC activation [42]. Our experiments with cell lines indicate that PKC activity supports migration of MDA-MB-231 cells. However, downregulation of $\mathrm{PKC} \alpha$ with siRNA in this cell line did not affect cell migration. MDA-MB-231 cells have high basal expression levels of $\mathrm{PKC} \alpha$ and incomplete downregulation of PKC $\alpha$ may explain the lack of effect on cell migration. This assumption is supported by the more efficiently suppressed wound healing upon downregulation of PKC $\alpha$ in MCF-7 cells. Our data therefore indicate that $\mathrm{PKC} \alpha$ activity is important for migration of breast cancer cells, in line with previous findings using PKC $\alpha$ overexpression. A migratory propensity might facilitate the metastasation of a tumor. However, our tumor data did not support a role for PKC $\alpha$ in dissemination. There was no correlation between PKC $\alpha$ expression and nodal or distant metastases. Thus, the effects of PKC $\alpha$ on migration may primarily be of importance in vitro.

For $\mathrm{PKC} \delta$ there is less information regarding expression levels in primary tumors. One study has shown that low levels of $\mathrm{PKC} \delta$, particularly in combination with high $\mathrm{PKC} \alpha$, predict resistance to endocrine therapy [8]. In this study, we could not observe any significant associations between $\mathrm{PKC} \delta$ expression and relevant clinicopathological parameters. Thus, altered PKC $\delta$ 


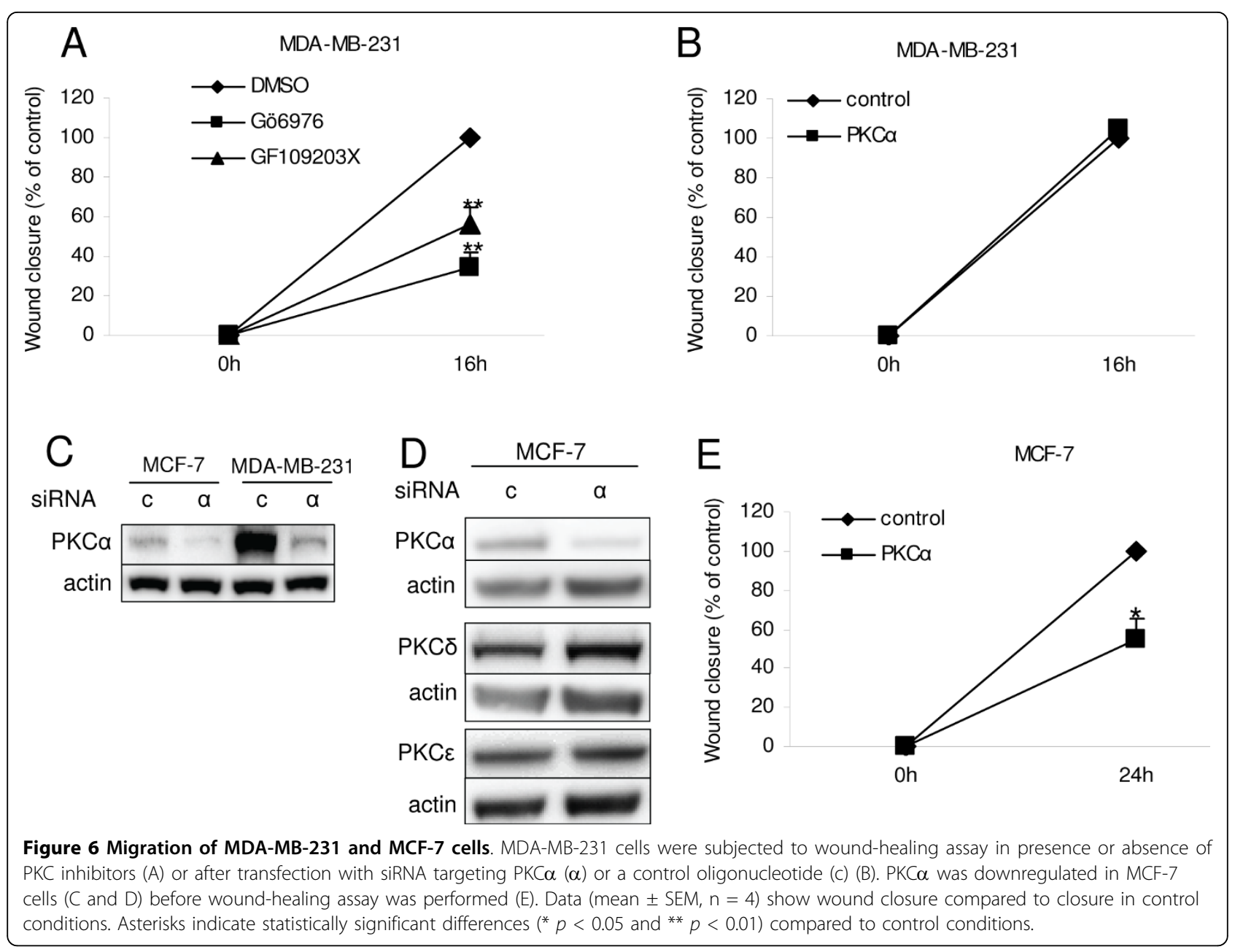

expression does not seem to be a prerequisite for breast cancer progression.

PKC $\varepsilon$ has been proposed to be a marker of aggressive breast cancer since its expression was reported to be elevated in hormone receptor-negative breast cancers with high tumor grade and HER2 amplification [22]. However, a relationship between PKC $\varepsilon$ expression and tumor grade could not be confirmed in this study, suggesting that it might not be apparent in cohorts representing all histological subtypes of breast cancer. It is possible that the level of PKC $\varepsilon$ is a marker of aggressiveness in more defined subgroups of breast cancer.

\section{Conclusions}

In conclusion, our findings demonstrate that expression of PKC $\alpha$ correlates to both ER and PR negativity as well as high histological grade and proliferation rate in breast cancer. An important role for PKC $\alpha$ in breast cancer cell proliferation was also observed in vitro. PKC $\alpha$ expression is not associated with metastasis in breast cancer samples, but PKC $\alpha$ activity supports migration of breast cancer cells in vitro. Importantly, PKC $\alpha$ expression predicts for a poorer 10-year breast cancer-specific survival, independently of established prognostic parameters. Thus, we propose that PKC $\alpha$ might be a useful marker for prognostication and treatment stratification in breast cancer.

\section{Acknowledgements}

We are grateful for excellent technical assistance from Elise Nilsson. This work was supported by grants from The Swedish Cancer Society, The Swedish Research Council, The Children's Cancer Foundation of Sweden, Malmö University Hospital Research Funds, and the Kock, Crafoord, Ollie and Elof Ericsson and Gunnar Nilsson Foundations.

\section{Authors' contributions}

GKL evaluated clinical samples, performed statistical analyses, participated in the design of and did most of the experimental work, and assembled the drafts of the manuscript.

LC did some experimental work.

IOZ took part in the evaluation of the antibodies and clinical samples. GL supervised the analysis of cohort I and participated in interpretative discussions. 
$\mathrm{KJ}$ supervised the analysis of cohort II and statistical analyses of patient data, and helped draft the manuscript.

$\mathrm{CL}$ conceived of the study, participated in the design of the experimental work and helped draft the manuscript.

All authors read and approved the final manuscript.

\section{Competing interests}

The authors declare that they have no competing interests.

Received: 3 November 2009 Accepted: 14 April 2010

Published: 14 April 2010

\section{References}

1. Vargo-Gogola T, Rosen JM: Modelling breast cancer: one size does not fit all. Nat Rev Cancer 2007, 7:659-672.

2. Sorlie T, Perou CM, Tibshirani R, Aas T, Geisler S, Johnsen H, Hastie T, Eisen MB, Rijn van de M, Jeffrey SS, et al: Gene expression patterns of breast carcinomas distinguish tumor subclasses with clinical implications. Proc Natl Acad Sci USA 2001, 98:10869-10874.

3. Newton AC: Protein kinase C: structural and spatial regulation by phosphorylation, cofactors, and macromolecular interactions. Chem Rev 2001, 101:2353-2364.

4. Ways DK, Kukoly CA, deVente J, Hooker JL, Bryant WO, Posekany KJ, Fletcher DJ, Cook PP, Parker PJ: MCF-7 breast cancer cells transfected with protein kinase $\mathrm{C}$ - $\alpha$ exhibit altered expression of other protein kinase $C$ isoforms and display a more aggressive neoplastic phenotype. J Clin Invest 1995, 95:1906-1915.

5. Chisamore MJ, Ahmed Y, Bentrem DJ, Jordan VC, Tonetti DA: Novel antitumor effect of estradiol in athymic mice injected with a T47D breast cancer cell line overexpressing protein kinase $\mathrm{C} \alpha$. Clin Cancer Res 2001, 7:3156-3165.

6. Tonetti DA, Chisamore MJ, Grdina W, Schurz H, Jordan VC: Stable transfection of protein kinase $\mathrm{C} \alpha$ cDNA in hormone-dependent breast cancer cell lines. Br J Cancer 2000, 83:782-791.

7. Tonetti DA, Morrow M, Kidwai N, Gupta A, Badve S: Elevated protein kinase $C \alpha$ expression may be predictive of tamoxifen treatment failure. Br J Cancer 2003, 88:1400-1402.

8. Assender JW, Gee JM, Lewis I, Ellis IO, Robertson JF, Nicholson RI: Protein kinase $C$ isoform expression as a predictor of disease outcome on endocrine therapy in breast cancer. J Clin Pathol 2007, 60:1216-1221.

9. Gill PK, Gescher A, Gant TW: Regulation of MDR1 promoter activity in human breast carcinoma cells by protein kinase $C$ isozymes alpha and theta. Eur J Biochem 2001, 268:4151-4157.

10. Blobe GC, Sachs CW, Khan WA, Fabbro D, Stabel S, Wetsel WC, Obeid LM, Fine RL, Hannun YA: Selective regulation of expression of protein kinase $\mathrm{C}(\mathrm{PKC})$ isoenzymes in multidrug-resistant MCF-7 cells. Functional significance of enhanced expression of PKC $\alpha$. J Biol Chem 1993, 268:658-664

11. Roychowdhury D, Lahn M: Antisense therapy directed to protein kinase C- $\alpha$ (Affinitak, LY900003/ISIS 3521): potential role in breast cancer. Semin Oncol 2003, 30:30-33

12. Ainsworth PD, Winstanley JH, Pearson JM, Bishop HM, Garrod DR: Protein kinase $\mathrm{C} \alpha$ expression in normal breast, ductal carcinoma in situ and invasive ductal carcinoma. Eur J Cancer 2004, 40:2269-2273.

13. Kerfoot C, Huang W, Rotenberg SA: Immunohistochemical analysis of advanced human breast carcinomas reveals downregulation of protein kinase C $\alpha$. J Histochem Cytochem 2004, 52:419-422.

14. Zeidan YH, Wu BX, Jenkins RW, Obeid LM, Hannun YA: A novel role for protein kinase $C \delta$-mediated phosphorylation of acid sphingomyelinase in UV light-induced mitochondrial injury. Faseb J 2008, 22:183-193.

15. McCracken MA, Miraglia LJ, McKay RA, Strobl JS: Protein kinase $C \delta$ is a prosurvival factor in human breast tumor cell lines. Mol Cancer Ther 2003, 2:273-281.

16. Nabha SM, Glaros S, Hong M, Lykkesfeldt AE, Schiff R, Osborne K, Reddy KB: Upregulation of PKC- $\delta$ contributes to antiestrogen resistance in mammary tumor cells. Oncogene 2005, 24:3166-3176.

17. Alonso-Escolano D, Medina C, Cieslik K, Radomski A, Jurasz P, SantosMartinez MJ, Jiffar T, Ruvolo P, Radomski MW: Protein kinase $C \delta$ mediates platelet-induced breast cancer cell invasion. J Pharmacol Exp Ther 2006, 318:373-380.
18. Kiley SC, Clark KJ, Duddy SK, Welch DR, Jaken S: Increased protein kinase $\mathrm{C} \delta$ in mammary tumor cells: relationship to transformtion and metastatic progression. Oncogene 1999, 18:6748-6757.

19. Kiley SC, Clark KJ, Goodnough M, Welch DR, Jaken S: Protein kinase $C \delta$ involvement in mammary tumor cell metastasis. Cancer Res 1999, 59:3230-3238.

20. Grossoni VC, Falbo KB, Kazanietz MG, de Kier Joffe ED, Urtreger AJ: Protein kinase $C \delta$ enhances proliferation and survival of murine mammary cells. Mol Carcinog 2007, 46:381-390.

21. Lønne GK, Masoumi KC, Lennartsson J, Larsson C: Protein kinase C $\delta$ supports survival of MDA-MB-231 breast cancer cells by suppressing the ERK1/2 pathway. J Biol Chem 2009, 284:33456-33465.

22. Pan Q, Bao LW, Kleer CG, Sabel MS, Griffith KA, Teknos TN, Merajver SD: Protein kinase $C \varepsilon$ is a predictive biomarker of aggressive breast cancer and a validated target for RNA interference anticancer therapy. Cancer Res 2005, 65:8366-8371.

23. Lu D, Sivaprasad U, Huang J, Shankar E, Morrow S, Basu A: Protein kinase C- $\varepsilon$ protects MCF-7 cells from TNF-mediated cell death by inhibiting Bax translocation. Apoptosis 2007.

24. Sivaprasad U, Shankar E, Basu A: Downregulation of Bid is associated with PKC $\varepsilon$-mediated TRAIL resistance. Cell Death Differ 2007, 14:851-860.

25. Lu D, Huang J, Basu A: Deregulation of PKB influences antiapoptotic signaling by PKC in breast cancer cells. Int J Oncol 2004, 25:671-676.

26. Zeidman $R$, Lofgren $B$, Pahlman $S$, Larsson C: PKC $\varepsilon$, via its regulatory domain and independently of its catalytic domain, induces neurite-like processes in neuroblastoma cells. J Cell Biol 1999, 145:713-726.

27. Nielsen NH, Arnerlov C, Emdin SO, Landberg G: Cyclin E overexpression, a negative prognostic factor in breast cancer with strong correlation to oestrogen receptor status. Br J Cancer 1996, 74:874-880.

28. Nielsen NH, Emdin SO, Cajander J, Landberg G: Deregulation of cyclin E and D1 in breast cancer is associated with inactivation of the retinoblastoma protein. Oncogene 1997, 14:295-304.

29. Roos G, Nilsson P, Cajander S, Nielsen NH, Arnerlov C, Landberg G: Telomerase activity in relation to p53 status and clinico-pathological parameters in breast cancer. Int J Cancer 1998, 79:343-348.

30. Svensson S, Jirstrom K, Ryden L, Roos G, Emdin S, Ostrowski MC, Landberg G: ERK phosphorylation is linked to VEGFR2 expression and Ets-2 phosphorylation in breast cancer and is associated with tamoxifen treatment resistance and small tumours with good prognosis. Oncogene 2005, 24:4370-4379.

31. Borgquist $\mathrm{S}$, Holm C, Stendahl M, Anagnostaki L, Landberg G, Jirstrom K: Oestrogen receptors $\alpha$ and $\beta$ show different associations to clinicopathological parameters and their co-expression might predict a better response to endocrine treatment in breast cancer. J Clin Pathol 2008, 61:197-203.

32. Helczynska K, Larsson A-M, Holmquist Mengelbier L, Bridges E, Fredlund E, Borgquist S, Landberg G, Pahlman S, Jirstrom K: Hypoxia-inducible factor$2 \alpha$ correlates to distant recurrence and poor outcome in invasive breast cancer. Cancer Res 2008, 68:9212-9220.

33. Raghunath A, Ling M, Larsson C: The catalytic domain limits the translocation of protein kinase $C \alpha$ in response to increases in $\mathrm{Ca} 2+$ and diacylglycerol. Biochem J 2003, 370:901-912.

34. Malyuchik SS, Kiyamova RG: Medullary breast carcinoma. Exp Oncol 2008, 30:96-101

35. Cameron AJ, Procyk KJ, Leitges M, Parker PJ: PKC $\alpha$ protein but not kinase activity is critical for glioma cell proliferation and survival. Int J Cancer 2008, 123:769-779.

36. $\mathrm{Ng} \mathrm{T}$, Shima D, Squire A, Bastiaens PI, Gschmeissner S, Humphries MJ, Parker PJ: PKC $\alpha$ regulates $\beta 1$ integrin-dependent cell motility through association and control of integrin traffic. Embo J 1999, 18:3909-3923.

37. Abeyweera TP, Chen X, Rotenberg SA: Phosphorylation of $\alpha$ 6-tubulin by protein kinase $C \alpha$ activates motility of human breast cells. J Biol Chem 2009.

38. Frankel LB, Lykkesfeldt $A E$, Hansen $J B$, Stenvang J: Protein Kinase $C \alpha$ is a marker for antiestrogen resistance and is involved in the growth of tamoxifen resistant human breast cancer cells. Breast Cancer Res Treat 2007, 104:165-179.

39. Lin $X, Y u Y$, Zhao H, Zhang $Y$, Manela J, Tonetti DA: Overexpression of PKC $\alpha$ is required to impart estradiol inhibition and tamoxifen-resistance in a T47D human breast cancer tumor model. Carcinogenesis 2006, 27:1538-1546. 
40. Yde CW, Gyrd-Hansen M, Lykkesfeldt AE, Issinger OG, Stenvang J: Breast cancer cells with acquired antiestrogen resistance are sensitized to cisplatin-induced cell death. Mol Cancer Ther 2007, 6:1869-1876.

41. de Vente JE, Kukoly CA, Bryant WO, Posekany KJ, Chen J, Fletcher DJ, Parker PJ, Pettit GJ, Lozano G, Cook PP, et al: Phorbol esters induce death in MCF-7 breast cancer cells with altered expression of protein kinase $C$ isoforms. Role for p53-independent induction of gadd- 45 in initiating death. J Clin Invest 1995, 96:1874-1886.

42. Parsons M, Keppler MD, Kline A, Messent A, Humphries MJ, Gilchrist $R$ Hart IR, Quittau-Prevostel C, Hughes WE, Parker PJ, Ng T: Site-directed perturbation of protein kinase C- integrin interaction blocks carcinoma cell chemotaxis. Mol Cell Biol 2002, 22:5897-5911.

doi:10.1186/1476-4598-9-76

Cite this article as: $L \varnothing n n e$ et al: PKC $\alpha$ expression is a marker for breast cancer aggressiveness. Molecular Cancer 2010 9:76.

\section{Submit your next manuscript to BioMed Central} and take full advantage of:

- Convenient online submission

- Thorough peer review

- No space constraints or color figure charges

- Immediate publication on acceptance

- Inclusion in PubMed, CAS, Scopus and Google Scholar

- Research which is freely available for redistribution

Submit your manuscript at www.biomedcentral.com/submit 